\title{
RETHINKING POPULIST DISCOURSE FROM LATIN AMERICA: ALGORITHMIC ACTIVISM AND THE CONSTITUTION OF A PEOPLE IN CHILE
}

\section{REPENSANDO O DISCURSO POPULISTA DA AMÉRICA LATINA: ATIVISMO ALGORITMICO E A CONSTITUIÇÃO DE UM POVO NO CHILE}

\section{Juan Eduardo Bonnin*}

\begin{abstract}
The aim of this article is to explore some of the ideological and empirical limits of studies on populism from a perspective based on Latin American history and theories, on one hand, and current ideas about digitalization and political discourse, on the other. I will first argue that studies on populism have a monolingual bias that conceals an ethnocentric view on academic research. As a consequence, when the term "populism" is applied to Latin American political discourse and history, it implies a pejorative view on democracies other than liberal European. Leaving aside this perspective, I will then present a different view of Latin American populisms, which allows for a richer, more complex perspective, including the key role of "the people" as a discursive actor that can even dispense with a populist leader, especially in the case of mediatized democracies. As a case study, I will analyze activism in Chile by observing Twitter's Trending Topics (TT) during the first week of the mass protests in October 2019. The analysis of TT hashtags helped us to better desccribe this process as one of handcrafted algorithmic activism which developed at least four tactics: the formulation of explicit demands, off-hours tweetstorms, syntagmatic variation, and HT confrontation and appropriation.
\end{abstract}

Keywords: algorithmic activism; populism; populist discourse.

\section{RESUMO}

O objetivo deste artigo é explorar alguns dos limites ideológicos e empíricos dos estudos sobre o populismo a partir de uma perspectiva baseada na história e em teorias latinoamericanas, por um lado, e em ideias atuais sobre digitalização e discurso político, por outro. Em primeiro lugar, argumento que os estudos sobre o populismo têm um preconceito monolíngue que encobre uma visão etnocêntrica sobre a investigação acadêmica. Como consequência, quando aplicado ao discurso político e à história da América Latina, o termo "populismo" implica uma visão pejorativa de outras democracias que não as europeias liberais. Deixando de lado essa perspectiva, apresento, então, uma visão diferente dos populismos latino-americanos, que dá lugar a uma perspectiva mais rica e complexa,

\footnotetext{
* Consejo Nacional de Investigaciones Científicas y Técnicas, CONICET, Argentina. bonninje@ gmail.com

Orcid: https://orcid.org/0000-0003-3459-0259
} 
incluindo o papel-chave do "povo" como ator discursivo que pode até mesmo dispensar um líder populista, especialmente no caso das democracias mediatizadas. Como estudo de caso, analiso o ativismo no Chile, observando os Trending Topics (TT) do Twitter durante a primeira semana dos protestos em massa, em outubro de 2019. A análise das hashtags de TT ajudou-nos a descrever melhor esse processo como um processo de ativismo algorítmico artesanal que desenvolveu pelo menos quatro táticas: a formulação de exigências explícitas, tuitaços na madrugada, variação sintagmática, e confrontação e apropriação de hashtags. Palavras-chave: ativismo algorítmico; populismo; discurso populista.

\section{INTRODUCTION}

The aim of this article is to explore some of the ideological and empirical limits of studies on populism from a perspective based on Latin American history and theories, on one hand, and current ideas about digitalization and political discourse, on the other.

I will first argue that studies on populism have a monolingual bias that conceals an ethnocentric view on academic research. As a consequence, when the term "populism" is applied to Latin American political discourse and history, it implies a pejorative view on democracies other than liberal European. Leaving aside this perspective, I will then present a different view of Latin American populisms, which allows for a richer, more complex perspective, including the key role of "the people" as a discursive actor that can even dispense with a populist leader, especially in the case of mediatized democracies. As a case study, I will analyze activism in Chile by observing Twitter's Trending Topics (TT) during the first week of the mass protests in October 2019.

\section{THE MONOLINGUAL BIAS IN STUDIES ON POPULISM}

Scholarly articles written in English about populism often ignore linguistic and discursive diversity. Driven by the need to include extremely different historical experiences, when these articles address the concept of "populism" as a "thin ideology" (STANLEY, 2008), that concept becomes increasingly at odds with a discursive approach.

On the one hand, this "ideology" is supposed to be based on core meanings such as "the people", "the elite" or the "charismatic leader". This superficial approach equates "ideology" to "signfiers", thereby ignoring that the sign "becomes an arena of class struggle" (VOLOSHINOV, 1929, p. 23). In other words, a shared lexicon does not mean a shared set of core meanings, but a common arena in which 
to struggle for different accentuation of those meanings. This is true not only of populist discourse, but also of every other kind of political discourse.

On the other hand, by using English as the sole language for designing and communicating scientific research - both data and theory - linguistic diversity is also obliterated, as there seems to be a transparent equivalency between the English word "people" and the Portuguese "povo", the Spanish "pueblo", the Italian "popolo", and so on.

\section{A brief conceptual overview}

Key concepts of political discourse, which are simultaneously instruments of analysis and arguments in the political dialogue, cannot be understood outside specific political traditions, because discourse is polyphonic and carries with it a memory of its past uses.

The term "populism" is no exception. It was originally a Russian term from 1878 (Narodnichestvo) which decades later was translated into different European languages as "populismo" or "populism", as R. Pipes explained in a classical study (PIPES, 1964). In this version, it described a progressive movement in Russia which was opposed to the upper classes, though it was not Marxist, being an agrarian, nationalist socialism. US and Western European scholars, however, rarely refer to Russian populism; instead, they usually identify the "inventors" of the term with the US People's Party (1891), also an agrarian, anti-elitist and anti-intellectual movement, much more accessible from a monolingual, English-speaking tradition. It is also from this US tradition that the term "populism" loses its descriptive sense, and begins to be used as derogatory, at least until E. Laclau's work On populist reason (2004).

Houwen (2011) points out that during the European inter-war period, Gramsci used neither "populista" nor "popolista", but rather, the term "popolare" (which he translates as "popularist", and in Spanish is "popular"). In his Prison notebooks, "popularism" is understood under a Christian ("Catholic") view of society as a harmonious totality which orients political action. From this standpoint, "il popolo" (or, in some Catholic-oriented left-wing political movements in Latin America, "el Pueblo") is at the same time an entity which exists despite conflict and social heterogeneity and a horizon of future wellbeing.

This view of acting for and from "the people", from outside the Englishspeaking, mainstream academic tradition, was overlooked by central academies (HOUWEN 2011). Therefore, as from the mid-1950s we observe a renewed, English-speaking tradition of sociopolitical thought about "populism" which 
uses the term as a pejorative concept to disqualify political experiences different from liberal, central democracies (ADAMOVSKY, 2016). From this standpoint, "populism" was intended to include phenomena such as the Ku-Klux-Klan, Mussolini's Italian Fascism, and the democratic governments of Juan Perón in Argentina and Getúlio Vargas in Brazil.

The People in Latin America: pueblo, gente and personas

In the Southern Cone of Latin America, the term "people" can be translated into Spanish either as "pueblo", "gente" or "personas", which all have completely different meanings.

The term "gente" is close to "citizenship", as defined by G. O’Donell (1979), and thus identified with a liberal conception of "citizens" as a group of individuals with equal political and civil rights. "Pueblo", however, as in Gramsci's "popolo", "is a carrier of demands for substantive justice which form the basis for the obligations of the state toward the less favored segments of the population" (O'DONELL, 1979, P. 289). "Personas", finally, are individuals not defined in political terms, and as such, they are not usually integrated to explicit political discourse (ARNOUX \& BONNIN, 2016).

Appeals to "la gente" or "el pueblo" (both translated as "the people") thus entail two different political traditions, both as a scholarly issue and as a social reality. When used exclusively in monolingual literature, this difference is overlooked: movements such as Varguism (Brazil), Peronism (Argentina), Aprism (Perú), and more recently, Cambiemos (Argentina), J. Bolsonaro (Brazil) or A. Uribe (Colombia) are based on discourse which appeals to the direct relationship between the leader and the people, but "people" can be understood either as "la gente", a group of individuals who make heterogenous claims in more or less articulated discourse, or "el pueblo", a collective entity that transcends individuals and draws on anti-liberal political traditions.

At the same time, the term used changes the addressee of both kinds of political discourses: the people/gente, being a sum of individuals, can derive easily in a singular "you" ("vos"/"tú"), establishing personal proximity between the leader and his/her audience. On the other hand, the people/pueblo is addressed as a plural "you" ("ustedes"), a complex entity which is different from the sum of its parts, but nonetheless a collective subject.

The people/pueblo is addressed as a political subject, defined by a collective project, more or less identified with an explicit ideology. The people/gente, on the other hand, is seen as a demographic subject: a series of sociological variables which 
allows for increasingly specific messages, targeted by social media's algorithms. "La gente" is quantitative in its nature: there is more "gente" because there are more individuals, and being "popular" (as in "massive") becomes a virtue. "El pueblo", on the other hand, is qualitative: it exists where it is named and recognized as such, in a plurality of stories and traditions, and being "popular" means being "authentic".

\section{POLITICAL DISCOURSE IN LATIN AMERICA: FROM POPULISM TO ALGORITHMIC ACTIVISM}

The monolingual bias in populist studies usually impoverishes the conceptual framework for understanding populist discourses, as the English term people might oversimplify other political concepts, such as the distinction between el pueblo and la gente.

Something very similar happens with regard to ideas about politics and democracy: when drawn from Western European and US traditions, they become a normative scale against which every other political culture is measured (MACKINNON \& PETRONE, 1999). From this point of view, taking as an almost ideal type of democracy the European parliamentary democracies of the second half of the $20^{\text {th }}$ Century, or the US liberal capitalist democracy in the same period, every divergence is seen as eroding the democratic quality of governments for being "interventionist", "nationalist", "paternalist", "traditionalist", etc. This is the case, notably, of US scholars researching Latin American politics and telling us why we are not sufficiently democratic (as WEYLAND 2011, p. 14 does). Even if many of these political movements integrated otherwise marginalized masses, granted fundamental rights in the political, economic and social areas and were popularly elected through universal vote, they are usually (dis)qualified as "non-democratic" or "less democratic".

One of the main differences between Latin American and mainstream studies on populism is that Latin American studies are usually more focused on the social conditions for the emergence of populist movements. As a consequence, the populist leader component is not only essential (as in Peru or Bolivia), but also theoretically weak, as it attempts to explain political processes from the standpoint of a charismatic individual (CHAMOSA, 2013; RETAMOZO, 2017).

Petrone \& Mackinnon (1999: 21) propose three minimum common attributes of the different experiences of "populism" in Latin America: a) a situation of crisis and change as a condition for its emergence; b) a participative dimension, substantive of democracy, which outweighs the representative dimension, which 
is typical of liberal democracies. c) an intrinsic historical ambiguity, as "in the public place, sometimes it is not clear who is speaking, the figure in the balcony or the crowd" (MACKINNON \& PETRONE, 1999, p. 22; my translation). From this standpoint, populist movements in Latin America are linked to contradictory processes, including domination and manipulation, but also liberation and agency.

In addition to these shared traits of populist movements in L-A, there are also two dimensions in which they differ from each other. Firstly, although populist discourse schematizes a simplistic opposition between "the people" and "the elites" (el pueblo and la oligarquía, etc.), actual historical experiences show widely differing bases for different experiences: Peronism and Varguism, in Argentina and Brazil, were movements with strong bourgeois and industrial working class components, while Mexican Cardenism was mainly a rural movement. Secondly, while some classic experiences of populism operated based on the logic of incorporating masses to social, economic and political rights by regulating and institutionalizing social demands (such as unions, retirements, etc.), other experiences operated by a selective incorporation of specific social sectors through focused social and economic programs, eroding previously existent institutional mechanisms and producing a form of fragmented integration.

Thus, by leaving aside an ethnocentric viewpoint on political systems, we can recognize at least two key aspects of Latin American populisms which are usually ignored in mainstream literature: a) they are more on the side of democratic participation than democratic representation (but democratic, nonetheless); b) populist leaders are not absolutely essential to populist governments or populist discourses. What these movements really need is a People-pueblo.

\section{Political discourse, algorithmic activism and the constitution of the People}

Mainstream discourse analysis usually emphasizes the dialogical nature of discourse as a constitutive feature of every social actor's voice. However, as Bolívar (2018) notes, there is often a contradiction between theoretical statements and analytical practice. The discussion of actual datasets usually only considers monologic discourse, such as "the discourse of Trump", "Chávez", etc. In more general terms, even though discourse analysis explicitly expresses interest in change and dialogue, it often involves very little systematic analysis of data of this kind and overlooks interaction, whereas it highlights processes of domination (BONNIN, 2019 a, p. 23).

With regard to populist discourse, this monologic perspective is reflected by the design of a corpus which represents a single stance (typically, a set of speeches 
by a speaker previously defined as a populist leader; cfr. HIDALGO-TENORIO, BENÍTEZ-CASTRO \& DE CESARE 2019). From this perspective, the "people" is seen simply as a "rhetorical means" (Canovan 1981), understanding "rhetoric" as something different from "ideology", in a non-theoretical understanding of "rhetoric" such Minogue's (1967) and, more recently, Macaulay's (2019). "The people" is also seen as an amorphous "silent majority" (TAGGART, 2002, p. 92) with no voice but that of the populist leader, who creates them as an undivided, homogeneous whole (TAGUIEFF, 1997) which remains fixed and static (MUDDE, 2004, p. 544). In the same vein, Wodak (2015) sees "the people" of the German extreme right-wing's discourse as a "homogeneous demos" defined arbitrarily by the populist speaker. Moreover, "populist discourse" can be understood as a "strategy" to exercise direct government power, with "the people" being the rhetorical resource which enables such a strategy (WEYLAND, 2001). Thus, as "the people" is said to lack any sociological or political objectivity, "it is the leader that should be our main focus when studying the phenomenon, given that leaders are the figures that ultimately 'do' populism" (MOFFITT, 2016, p. 51). Even analyzing intrinsically dialogic platforms, as social media, a monologic view prevails by analyzing only decontextualized posts or tweets by political leaders (cf. GARCÍA MARÍN \& LUENGO 2019).

This monologic approach is not compatible with a Latin American perspective such as the one outlined in the previous section. The position I will argue for with regard to the analysis of populist discourse is that it cannot be understood without some kind of attention to the actual communicative materiality of "the people", not as a rhetorical figure used by populist leaders or as an argumentative gambit, but as a necessary condition for this kind of discourse to exist.

In this regard, I will draw on E. Laclau (2005) and Maly (2018), who both propose, from different perspectives, a new understanding of the role of "the people" in populist discourse.

Laclau (2005) argues for the existence of the People-Pueblo as an entity previously dismissed as a sociological aberration or a rhetorical alibi. Laclau considers populism to be a social logic for the construction of politics. Therefore, populism cannot be understood unless we comprehend how its key component - a people that recognizes the popular leader as such - comes into existence. From his perspective, the people is not a preexisting entity which is manipulated by the leader, but a complex social identity which is created by establishing an equivalential chain between heterogeneous demands (which he calls "democratic demands") as a set of "popular demands" unified by an empty signifier. Thus, "the people" 
simultaneously creates the populist leader (as it demands for the recognition of its heterogeneous demands) and is created by the populist leader (as its unity is an effect of an equivalence chain established by the populist leader, which thus transforms democratic into popular demands). Therefore, we cannot understand populist discourse without observing which sets of heterogeneous demands are understood as an equivalence chain unified by a given empty signifier. In other words, we cannot understand populism if we do not look at those heterogeneous social demands that become the discursive and political substance of its discourse.

This understanding of populism, though recent, has been applied to classical, $20^{\text {th }}$ century phenomena by Laclau himself. When looking at current, 21 st century populisms, it becomes even more apparent that we cannot ignore the role of "the people" as a collective, heterogeneous speaker which constitutes itself by discursive means, and by demanding an empty signifier capable of establishing the equivalence among its heterogeneous demands. This process of recognition and constitution, however, no longer relies on human agents. As Maly (2018) has pointed out, social algorithms play a key role in creating the "popularity" of "populist" discourses in digital media. The way in which social subjects interact with non-human agents enables new forms of (distributed) agency for political discourse and action (PENNYCOOK, 2018). Social media thus play the role of the populist leader in establishing the equivalence of the demands and thereby the constitution of a leaderless People-Pueblo in a more radical form of algorithmic populism based on computational agency (MALY, 2019).

However, this process requires a specific form of interaction with social media called algorithmic activism, which potentiates the political content through active (and planned) use of the medium's affordances and internal logic (cf. VELKOVA \& KAUN, 2019). In other words, "algorithmic activists use (theoretical or practical) knowledge about the relative weight that certain signals have within the proceduralized choices made by the algorithms of the media platforms as proxies of human judgment, in relation to the goals of the medium itself" (MALY, 2019).

\section{HASHTAG ACTIVISM AND THE CONSTITUTION OF THE CHILEAN PEOPLE: OCTOBER 2019}

So far, I have established a series of starting points from which to analyze some forms of current populist discourse. Firstly, the existence of an English monolingual bias in studies on populism prevents the description and understanding of specific political processes by deleting their linguistic (i.e., cultural) singularities. Linked to 
this, central academies have an ethnocentric view of political processes which are unlike their own experiences; thus, "populist" has become a pejorative term used to measure these differences. When using other sources of political and discourse theory, we understand other realities better; in particular, Latin America has already had populism without populists, because of the specific weight of the People-pueblo, not defined as a pre-existent demographic entity, but as a complex social identity constituted in the interaction with an agent capable of establishing the equivalence of heterogeneous social demands. Algorithmic populism and activism can be achieved through distributed human-machine agency.

I will use this critical conceptual framework to provide understanding of the case of algorithmic activism in Chile during the first week of the massive protests which led to a process of social and political change which is still ongoing.

On October $14^{\text {th }}$, a 3.7\% metro fare price hike in Chile's capital city, Santiago, sparked massive protests. Students called for massive fare evasion using the hashtag \# evasionmasiva ("massive evasion"), widely distributed and well documented on social media. As a reaction, the government sent to the metro stations carabineros (local militarized police), who repressed teenagers with tear gas, sticks and riot guns. People on the streets began to show massive support for the students' evasion, while President Sebastian Piñera was shown on social media with his family at a pizza place, an image that was interpreted as a proof of indifference to social reality. The following day, Saturday, Piñera imposed a state of emergency and curfew across the country, sending military forces to the main cities for the first time since the military dictatorship of Augusto Pinochet.

This was too much: "it's not 30 pesos, it's 30 years" was a phrase which explained why hundreds of thousands of people went out into the streets, defying the state of emergency and curfew, to protest against political authoritarianism and social and economic inequality. A self-organized demonstration of more than 1,200,000 people in Santiago was followed by more protests. Yet the military forces began to repress protesters violently: more than 20 confirmed deaths, hundreds of rapes and sexual abuses, thousands of injured and tortured persons in jails, and hundreds of civilians kidnapped from their homes by carabineros.

In Latin American Spanish-speaking political tradition there is as term for this kind of violent, massive street protests and riots which are not directed by any distinguishable leader or movement and bring together heterogeneous demands: pueblada. Derived from "pueblo", the puebladas can be understood as a key part of constituting a People, as it becomes a community only through (and because of) shared action. In the case of digitalization, as Blommaert (2019) notes, community 
is a consequence, not a condition, for mediatized action. Social media's algorithmic agency, thus, is the matter - not just the medium - of this action, based on the online-offline continuum (BLOMMAERT, 2019).

The role of social media in creating a People-Pueblo

Massive social violence in Chile was strongly based on social media. It took place a decade after the Arab Spring, which is usually recognized as the first case (or, at least, the first case to be successful) of social protest organized through social media, or mediatized social protest (CHRISTENSEN \& CHRISTENSEN, 2013; KARATZOGIANNI, 2013), which also helped establish the idea of social media as a democratic, participatory, anti-authoritarian platform, still far from the obscure use of users' data and deals with authoritarian governments that were revealed in later years.

Twenty-eight percent of the Chilean population uses Twitter at least once a day. And though less popular than Facebook or Instagram, it is the preferred platform for following politicians and discussing politics (CADEM - JELLY, 2019).

Analysis of the early days of the protest, which began on October $14^{\text {th }}, 2019$, shows that Trending Topics in Chile were dominated by the protesters' demands. The first reason for the protest was the infinitesimal increase in the metro fare (US\$ 0.30), and the response by high school students was "evasión": evading the payment of the fare by fare-dodging. These actions were not taken individually but massively, not only as a way to avoid being captured by the police, but also as a way to constitute a collective identity. \#EvasionMasiva ("mass evasion") was the hashtag used to call for this action during the first week of protest. As it was also written on handmade banners, the HT was simultaneously an online and offline expression. 


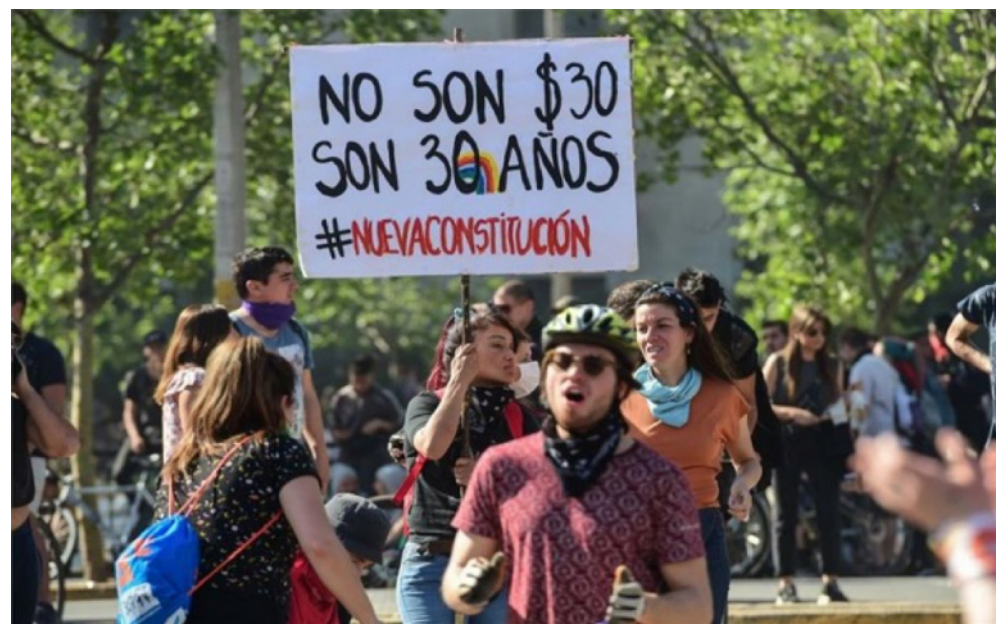

Figure 1.

After two intense months of violent protests, repression, torture and other human rights violations (BONNIN, 2019b), only a few government officials had resigned and some political measures had been taken in response to popular demands: a shorter workweek, lower road tolls and most importantly, a referendum to create a new Constitution to replace the one sanctioned by the dictatorship of A. Pinochet in 1980. The new Constitution is expected to be more democratic, not only in terms of the political system, but also in terms of redistribution of wealth and more egalitarian access to education, healthcare and pensions.

The first week of the protests is especially interesting to observe, as the online-offline continuum was apparent: the hashtag \#EvasiónMasiva ("Mass evasion") was Trending Topic all day on October 15, while thousands of students en masse evaded metro fares in protest against the latest increase. While these students were being repressed by the Chilean police (the carabineros, deprecatorily known as "pacos"), offline shouts of "iPacos culiaos!" ("Fuckin' Pacos!") during protests were transmitted via Twitter with the hashtag \#PacosCuliaos, a recurrent HT in the TT list. By the end of the week, while approximately 1.2 million people demonstrated in Chile's biggest march, more than 506 thousand tweets had shared texts, pictures and videos with the HT \#LaMarchaMasGrandeDeChile ("Chile's biggest march").

Protest hashtags were used to encourage affirmative actions of civil disobedience, either regarding the metro fare or the curfew imposed by President Piñera. At the same time, anti-protest hashtags were used to challenge and compete for prominent TT places in the Twitter confrontation. To confront \#EvasiónMasiva, 
the judgmental \#EvadirEsRobar ("Evading is stealing") condemning the metro fare evasion was launched, with some success. This "anti" HT, however, would be rapidly counter-attacked, either by appropriation (using it to spread protesting content, thereby subverting its original aim) or rewording (propelling the HT \#EvadirEsLuchar, "Evading is fighting", which contradicts its meaning and recalls the original formulation).

Since 2016, Twitter has developed a more active policy towards automated campaigns aimed at imposing Trending Topics (TT) in the platform (ROTH \& HARVEY, 2018). It therefore uses some measures of speed, synchronicity, similarity of content, etc. - also automated - to detect and deactivate bot campaigning. With bots hiding behind better constructed profiles, human networks and even human agents, current tactics of algorithmic activism involve handcrafted communicative actions. I will describe four of them.

\section{Formulating explicit demands}

Adopting the view of Laclau (2004), there cannot be populism without popular demands, i.e. a set of heterogeneous demands that become a series only through populist discourse. The existence of a People without a populist leader is not contrary to this process, as this kind of mediatized communication is enabled by algorithmic means. By establishing and ranking trending topics, Twitter presents the "chain of equivalence" of popular demands. Twitter thus becomes not only one of the media, but one of the actual mechanisms through which the People-pueblo constitutes itself.

The basic HT mood, therefore, is the imperative, as it establishes an interpersonal relationship in which both participants, the people-pueblo and the addressee, are defined. During the first days of the protest, the protest HTs that trended atop Twitter's TT ranking were mainly descriptions or calls to action to other participants, such as those analyzed above (\#EvasiónMasiva, \#EvasiónTodoElDía, \# MetroSantiago, etc.). The first imperative HT trended at 9PM on October 18 and would remain a classic: \#RenunciaPiñera ("Piñera, quit"). There were also frequent demands for the resignation of other government officials: \#FueraChadwick, \#FueraRubilar, \#FueraBoric, \#FueraCariola ("Chadwick, out", "Rubilar, out", "Boric out", "Cariola out").

However, as timewent by, these specific demands became moreheterogeneous. Some were aimed at a more abstract reference: \#NeoliberalismoNuncaMás ("Neoliberalism never again"), \#QueSeVayanLosMilicos ("We want the military out"); others, to specific legislative measures, like \#RebajaDietaParlamentaria 
("Lower Representative Salaries"), \#NoTag ("No Tag", demanding a reduction in the cost of road tolls) or \#AcusaciónConstitucionalPiñera ("Impeach Piñera").

Perhaps the most relevant process in constituting this people-pueblo through hashtags can be observed in the ideational meanings they proposed. During the three first days, TTs were mainly nominalizations, i.e., grammatical metaphors with no agent, as in \#EvasiónMasiva, \#EvasiónMetro, \#EvasiónTodoElDía or \#ParoNacional. On October 18, at 7AM, a grammatical subject appeared, but as a singular pronoun: \#YaNoTeTengoMiedo ("I am not afraid from you anymore"). At the same time as the first person singular, the second person singular also appeared: \#RenunciaPiñera ("Piñera Quit") for the first time as a TT on the same day at 9PM. It was on October 19 that a collective subject expressed, for the first time, its demands as a people-pueblo: \#ChileDespierta ("Chile Wakes up"), reaching second position at 5AM. From that point on, a collective subject was also used, either presented as a "we" (\#NosCansamos, "We are fed up"; \#NoEstamosEnGuerra, "We are not at war"), or identified with Chile (\#ChileEnResistencia, "Chile resists"; \#ChileEstáDespertando, "Chile is awakening").

This collective subject acquired its critical mass through social media, which was capable of establishing the equivalence of a series of heterogeneous demands that only subsequently proved to be constitutive of a people-pueblo. It was also recognized as such thanks to social media visibility, not only by supporters but, especially, by opponents, thereby helping to create this agonistic people-pueblo.

\section{Off-hour tweetstorms}

TTs are not established based solely on the number of tweets or number of people tweeting. For a topic or hashtag to be considered a TT, it has to be recently popular, or popular to a new group of users. It is therefore easier for a topic to trend when there is a low baseline (TWITTER, 2010), either because there are fewer users or because users are still discussing old topics. For algorithmic activism, offhour tweetstorms are ideal, not only because of the "Trending topic" badge, but especially because they will remain at the top during the first hours of the morning, thus influencing online and offline conversations, including radio and TV.

We can identify three main features for this kind of tactics: a) the preferred hours for these tactic tweetstorms are between 1 and $4 \mathrm{AM}_{i}$ b) they present a sudden rise in activity, in a short time lapse, with a relatively small amount of tweets; c) they are written as hashtags, usually using uppercase to segment words, and index very specific, ideologically identified meanings.

For instance, on October 20 at $1 \mathrm{AM}$ we observe the following trending HT. 


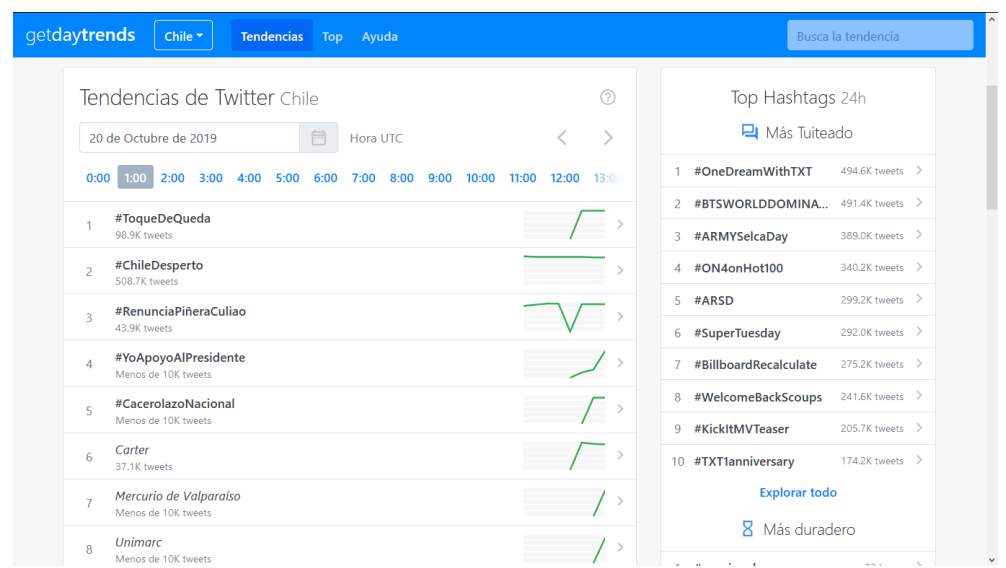

Figure 2.

Topic activity during the last 8 hours, on the right, shows the stability of the first 4 HTs. The second one, \#ChileDesperto, had more than half a million tweets and stayed atop the TT, as the green line on the right shows. However, this very stability is a reason not to be the number $1 \mathrm{TT}$, as it was replaced by a less popular (98.9K) but rapidly growing TT \#ToqueDeQueda.

By 2AM, however, the TT list had changed significantly.

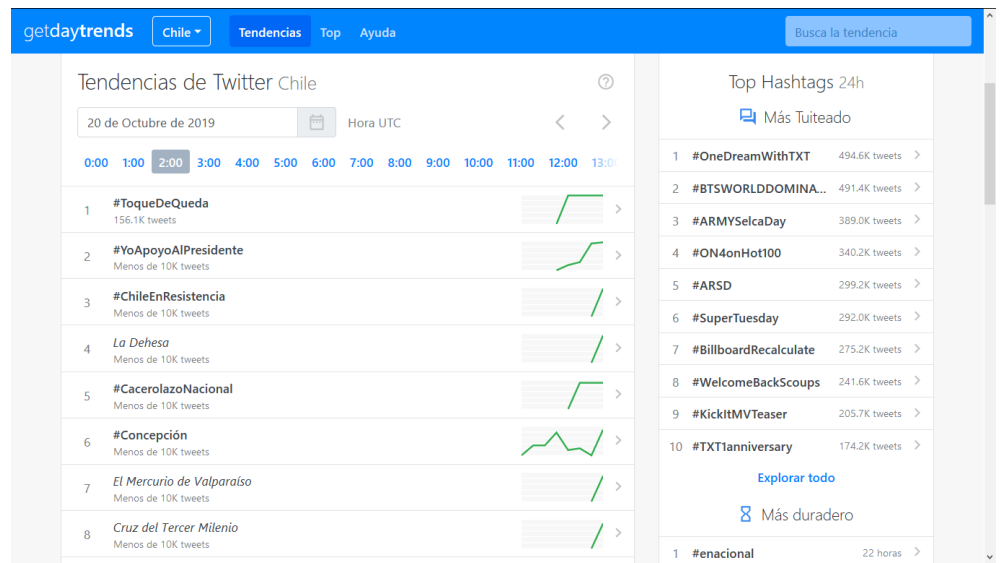

Figure 3.

\#ChileEnResistencia (\#ChileIsResisting) climbed to $3^{\text {rd }}$ place out of nowhere, with a relatively small number of tweets (less than $10 \mathrm{~K}$, which is the lowest amount the system registers) in a very short time span. Besides, it has a very 
identifiable left-wing flavor in the term "resistencia" ("resistance"), which is unlikely to emerge from more moderate, center users. As a result, it gained visibility for a short time, but disappeared from the TT list at 3AM.

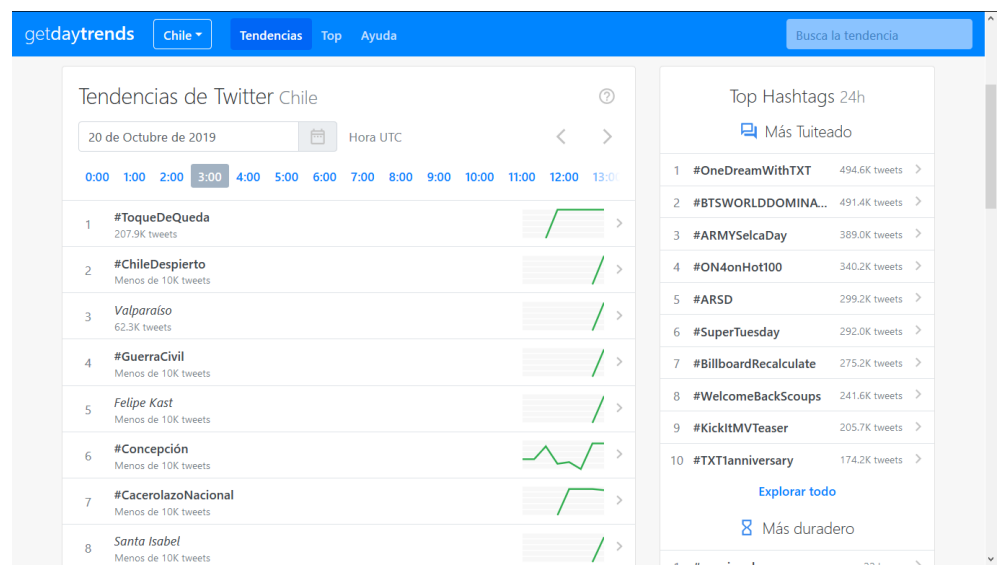

Figure 4.

At this time, while many HTs were still trending after many hours of use (\#ToqueDeQueda, \#Concepción, \#CacerolazoNacional), two new ones appeared, both in the very early hours of the day, forming a short phrase and using uppercase letters to segment words, with less than $10 \mathrm{~K}$ tweets each. Number 4 is \#GuerraCivil (\#CivilWar), an ideologically extreme denomination used to describe the situation of social and political violence. As can be seen, this HT was used in a tactic tweetstorm but lost traction because it was not adopted by other users.

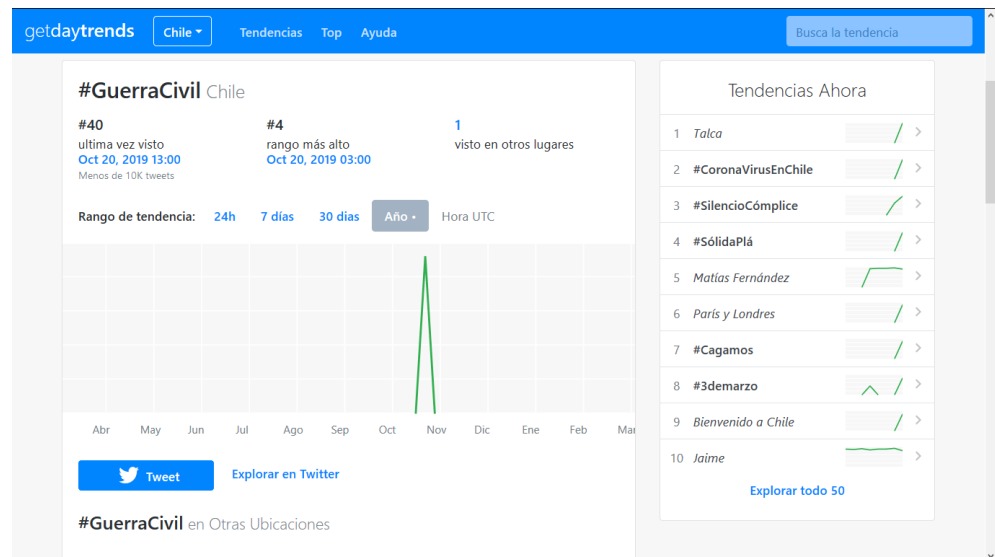

Figure 5. 
The other HT in this context was \#ChileDespierto (\#ChileAwake). Not only was it the result of early tweetstorm tactics, but also, it used syntagmatic variation.

3. Syntagmatic variation: wording and orthography

In Figure 2, we see that at $1 \mathrm{AM}$ \#ChileDespierto had trended atop Twitter all day, with an impressive number of hourly tweets. At 2AM, however, it disappeared from the ranking, either because of a sudden loss of messages or, more probably, because of the redundancy of the users' network; in other words, because no new people were tweeting about it.

However, small syntagmatic variations (either in wording or orthography) count as new topics, especially under the form of a hashtag, which is only counted according to its exact spelling. This is why the small variation from \#ChileDesperto (\#ChileAwoke) to \#ChileDespierto (\#ChileAwake) - only one letter in Spanish - enabled the sudden reappearance of the topic as a TT, still with less than $10 \mathrm{k}$ tweets, but recognizable and retweetable nevertheless, with potential to remain in the ranking for several more hours, as it did until 11AM.

This syntagmatic variation, with the purpose of introducing formal changes and thereby renewing the same topics under new forms, allowed for some playful spelling:

- Changing the verb. As mentioned above, changing the verb not only changes the form, but also the meaning of the HT, in this case, passing from an action ("Chile despertó", "awoke") to a state which is a consequence of that action ("Chile [está] despierto", "is awake").

- Challenging spelling rules. The first variation of this kind was registered on October 16, when after 24 hours of TT, the HT \# evasionmasiva ("massive evasion") began to disappear from the TT ranking. Then, the "misspelled" version \#EvacionMasiva ("massive evacion", spelled with a " $\mathrm{c}$ " in place of the " $\mathrm{s}$ "), appeared third in the ranking at $1 \mathrm{PM}$, securing first place until $8 \mathrm{PM}$.

- Misspelling proper names. The main target of misspelling was Chilean president, Sebastián Piñera, whose name appeared in several HTs which were then transformed via misspellings: \#PiñeraDictador became \#PineiraDictador. In other cases, different syntagmatic variations were combined: \#RenunciaPiñera was first misspelled as \#RenunciaPineira, and then reordered as \#PinedaRenuncia (a plausible tactic which I only found once). 


\section{HT confrontation and appropriation}

Political discourse cannot exist without an opponent; not only a metaphorical one, but an actual antagonist against which the speaker (whether individual or collective) can position and define himself/herself/themselves. In the case of populist discourse, it has been said that the Manichaeistic opposition between "people" and "elites" (which in Latin America is usually described as "pueblo" and "oligarquia" or "anti-pueblo"). In the case of Chile, during the first week of protest, we can observe the existence of Protest Hashtags (PHT) and Anti-Protest HT (AHT), the latter allegedly launched by government agents or trolls in order to dispute the TT Rank.

I found 16 Anti-Hashtags, i.e., HTs designed to compete for the first places as a TT in a more or less explicit opposition to PHTs. They are usually combined, sharing different positions in the TT Ranking. On October $18^{\text {th }}$ at 3 PM, the HT \#EvadirEsRobar ("Evading is stealing") appeared in $2^{\text {nd }}$ place, and remained there for five hours, until 8PM. At 10PM, \#AquíFaltaPinochet ("We miss Pinochet here") was in $6^{\text {th }}$ place, rising to $2^{\text {nd }}$ place at $11 \mathrm{PM}$.

Something similar happened over the next days: on October $19^{\text {th }}$, the AHT were: \#AquíFaltaPinochet (a remnant from the previous day, which survived until 5AM) and, at 7AM, \#MilicosALaCalle ("cops on the streets"), which is also a strong call for repression. That same day, which was very violent both in students' protests and carabineros' repression, two more AHTs were launched as TT: \#LimpiemosLaEstación ("Let's Clean The Station"), which was officially endorsed by Piñera's government, reached $2^{\text {nd }}$ place at $4 \mathrm{PM}$, and \#ToqueDeQuedaYa ("Curfew Now") came $4^{\text {th }}$ at 9PM. The former was less confrontational, adhering to generally positive values, while the latter was another call for repression, demanding a measure which had not been adopted since Pinochet's dictatorship.

On October 23 again, there were two AHTs. The first is explicitly polemic, reminiscent of traditional right-wing, anti-communist discourse: \#FueraComunistas ("Communists Out") in the early morning. It appeared at $2 \mathrm{AM}$ in $5^{\text {th }}$ place and remained among the TT until 7AM. A slight variation, \#FueraComunismoDeChile ("Communism Out Of Chile") had an ephemeral lifespan at 11AM. On the same day, the positive AHT was \#PiñeraEstoyContigo ("Piñera I Am With You"), which had a short lifespan at $3 \mathrm{AM}$ in $2^{\text {nd }}$ place.

Two types of anti-hashtags can be distinguished. The Positive AHT indexes what is commonsensically seen as a positive value, or what is supposed to be consensual meaning, such as the following: \#EvadirEsRobar (Oct. 18), \#LimpiemosLaEstacion (Oct. 19), \#YoApoyoAlPresidente (Oct. 20), 
\#PazParaChile (Oct. 21), \#PiñeraEstoyContigo (Oct. 22), ChileQuierePaz (Oct. 22), \#NuevaAgendaSocial (Oct. 23), \#ChileSomosTodos (Oct. 23 and the first hours of Oct. 24). The Polemic AHT, on the other hand, indexes explicit polemic meanings, usually identified with a conservative support for repression or status quo, such as the following: \#SantiagoNoEsChile (Oct. 17), \#AquiFaltaPinochet (Oct. 19), \#MilicosALaCalle (Oct. 19), \#ToqueDeQuedaYa (Oct. 19), \#DondeEstaBachelet (Oct. 21), \#FueraComunistas (Oct. 22), \#FueraComunismoDeChile (Oct. 22), \#EstoNoPrendio (Oct. 25).

There is roughly half of each kind. At the same time, there is an appropriation of these AHT by protesters, who use them in anti-government tweets. When the anti-hashtag "\#EvadirEsRobar" was launched by government officials and influencers, it was quickly used to promote pro-protest messages:

\#EvadingIsStealing Hahaha did these fascists really propel this HT? Fortunately, in this country are students and other people protesting and demanding their rights, if we only had submissive fuckers like you, we would pay to breathe.

\#EvadirEsRobar Jajajaja enserio los fachos sacaron este HT? menos mal en este país están los estudiantes y otras personas que protestan y reclaman por sus derechos, si hubieran puros weones sometidos como ustedes tendríamos que pagar hasta por respirar. https://twitter.com/ChileBicampeon/status/1185257109761462273) (October 18)

We can thus see PHTs and AHTs as successive exchanges in an argument. The first and most evident exchange was around the definition of "Evadir" ("Evade"). Confronting the first PHT, \#EvasionMasiva (Oct. 17), the following day (Oct. 18) \#EvadirEsRobar ("Evading Is Stealing") appeared, a moral and legal reinterpretation of the protest act par excellence. However, on Oct. 19, a new definition appeared as a PHT: \#EvadirEsLuchar ("Evading Is Fighting")

A second exchange occurred around the figure of President Sebastián Piñera. On Oct. 19 the PHT \#RenunciaPiñeraCuliao ("Quit Piñera Fuck") appeared, which is the first to explicitly addresses Piñera. The following day saw the response: \#YoApoyoAlPresidente ("I Support The President"); at 1AM they were side by side as TT numbers 1 and 2, and they shared the TT list throughout most of the day. On Oct. 20, a new PHT appeared, \#PiñeraRenuncia ("Piñera Quit"), which was responded to on the next day at 3AM: \#PiñeraEstoyContigo ("I Support You Piñera"). However, a new response appeared at 4AM: \#PiñeraDictador ("Piñera Dictator").

More localized exchanges can be seen in short timespans, such as on Oct 19 at 8AM, the AHT \#MilicosALaCalle ("Cops On The Streets") was responded 
at 9AM with \#MilicosSinGloria ("Cops Without Glory"). On Oct 23, the AHT \#ChileSomosTodos ("We All Are Chile"), was responded to at $12 \mathrm{AM}$, with the hugely successful \#ChileViolatesHumanRights at 4PM, struggling for the definition of "Chile" (as the People or the Government), targeting a global addressee, hence the use of English. Finally, on Oct. 25, the day of the demonstration, the main PHT \#LaMarchaMasGrandeDeChile ("Chile’s Biggest Demonstration") was responded to by \#EstoNoPrendio ("This Didn't Work"), both sharing first and second place as TTs. However, the numbers are extremely different: at its peak, at $11 \mathrm{PM}$, the PHTs had 285.5k tweets per hour, while the AHTs had 16k.

\section{CONCLUDING REMARKS}

In this article, I have made a critique of mainstream analysis of "populist discourse" as a monolingual, ethnocentric apparatus that reproduces global inequality. It does so firstly by establishing a liberal paradigm of non-populist, parliamentary representative democracies which de-legitimize alternative political dynamics. Secondly, these studies reproduce a global academic status quo which prevents peripheral theories from discussing their own realities. By displacing the focus to populist social dynamics in contemporary Latin America, I observe the centrality of the People, as both a complex social identity and a discursive agent which is constituted in interaction with social media. For the case of algorithmic populism and activism, it can be achieved through distributed human-machine agency.

I used this ideas to provide understanding of the discursive process of constitution of the Chilean People in the first week of the historical protests that took place in October, 2019. The analysis of TT hashtags helped us to better describe this process as one of handcrafted algorithmic activism which developed at least four tactics: the formulation of explicit demands, off-hours tweetstorms, syntagmatic variation, and HT confrontation and appropriation.

As the protests in Chile developed over the following months, it became more apparent that direct political action was inseparable from algorithmic activism, not as a form of dettached hacktivism, but as a part of an online-offline continuum. Many of the demands thus formulated have already been satisfied, and the most important one, a new Constitution, is to be voted on April 26, 2020.

At the edges of political and discursive theory, a Chilean People becomes the agent of its own contradictory and utopic discourse. 


\section{REFERENCES}

ADAMOVSKY, E. (2016). ¿De qué hablamos cuando hablamos de populismo? In Revista Anfibia. Available at: http://revistaanfibia.com/ensayo/de-que-hablamos-cuandohablamos-de-populismo-2/. Accessed: March 10, 2020.

ARNOUX, E. B. N.; Bonnin, J. E. (2016). Discourse and Politics. In: Lacorte, Manel (Ed.), The Routledge Handbook of Applied Hispanic Linguistics. London and New York: Routledge, pp. 551-568.

BLOMMAERT, J. (2019) Online with Garfinkel. Essays on social action in the onlineoffline nexus. Tilburg Papers in Culture Studies, $\mathrm{N}^{\circ}$ 229. Available at: https://www. tilburguniversity.edu/sites/default/files/download/TPCS_229-Blommaert.pdf.. Accessed: March 10, 2020.

BOLÍlVAR, A. (2018). Political Discourse as Dialogue: a Latin American Perspective. London and New York: Routledge.

BONNIN, J. E. (2019 a). Discourse and Mental Health. Voice, Inequality and Resistance in Medical Settings. London and New York: Routledge,

BONNIN, J. E. (2019 b). Chile violates human rights (and everyone can see it on Twitter). Diggit magazine. Available at: https://www.diggitmagazine.com/column/chile-violateshuman-rights. Accessed: March 10, 2020.

CADEM - JELLY (2019). El Chile que viene. Uso de redes sociales. Available at: https:// www.anda.cl/wp-content/uploads/2019/04/Estudio-El-Chile-que-Viene_RedesSociales.pdf. Accessed: March 10, 2020.

CANOVAN, M. (1981). Populism. London: Junction.

CHAMOSA, O. (2013). Populismo: crítica a la utilidad de un concepto peyorativo. Nuevo mundo Mundos nuevos, Colloques. Available at: https://journals.openedition.org/ nuevomundo/64836. Accessed: March 10, 2020.

CHRISTENSEN, M; CHRISTENSEN, C. (2013). The Arab Spring As Meta-Event and Communicative Spaces. Television \& New Media, v. 14, n. 4, pp. 351-364.

GARCÍA-MARÍN, G; LUENGO, O. G. (2019). Populist Discourse in the 21 st Century: the definition of otherness on Twitter in the cases of Spain, Bolivia and Venezuela. In: Hidalgo-Tenorio, E.; Benítez-Castro, M. A.; De Cesare, F. (Eds.), Populist 
Discourse. Critical Approaches to Contemporary Politics. London and New York: Routledge, pp. 81-99.

HIDAlGO-TENORIO, E.; BENÍTEZ-CASTRO, M. A.; DE CESARE, F. (2019). Introduction. In: Hidalgo-Tenorio, E.; Benítez-Castro, M. A.; De Cesare, F. (Eds.), Populist Discourse. Critical Approaches to Contemporary Politics. London and New York: Routledge, pp. 1-13.

HOUWEN, T. (2011). The non european roots of the concept of populism. Sussex European Institute Working Paper, N 120. Available at: https://www.sussex.ac.uk/webteam/gateway/ file.php? name $=$ sei-working-paper-no-120.pdf\&site $=266$. Accessed: March 10, 2020.

KARATZOGIANNI, A. (2013). A Cyberconflict Analysis of the 2011 Arab Spring Uprisings. In: G. Young, G. (Ed.), Digital World: Connectivity, Creativity and Rights. London and New York: Routledge, pp.159-175.

LACLAU, E. (2005). On Populist Reason. London: Verso.

MACAULAY, M. (2019). A Short Introduction to Populism. In: Macaulay, M. (Ed.), Populist Discourse: International Perspectives. New York: Palgrave Macmillan, pp. 1-26.

MALY, I. (2018). Populism as a mediatized communicative relation: The birth of algorithmic populism. Tilburg Papers in Culture Studies, $\mathrm{N}^{\circ}$ 213. Available at: https:// www.researchgate.net/publication/328095323_Populism_as_a_mediatized_ communicative_relation_The_birth_of_algorithmic_populism. Accessed: March 10,2020 .

MALY, I. (2019). Algorithmic populism and algorithmic activism. Diggit Magazine. Available at: https://www.diggitmagazine.com/articles/algorithmic-populism-activism. Accessed: March 10, 2020.

MINOGUE, K. (1969). Populism as a political movement. In: Ionescu, G.; Gellner, E. (Eds.), Populism: Its Meanings and National Characteristics. . London: Weidenfeld and Nicolson, pp. 197-211.

MOFFITT, B. (2016). The global rise of populism. Stanford: Stanford University Press.

MUDDE, C. (2004). The Populist Zeitgeist. Government and Opposition, v. 39, n. 4, pp. 541-563.

O’DONELL, G. (1979). Tensions in the Bureaucratic-Authoritarian State and the Question of Democracy. In: Collier, D. (Ed.), The New Authoritarianism in Latin America. Princeton: Princeton University Press, pp. 363-397. 
MACKINNON, M; PETRONE, M. (1999). Los complejos de la Cenicienta. In: MACKINNON, M; PETRONE, M. (Eds.), Populismo y Neopopulismo en América Latina. Buenos Aires: Eudeba.

PIPES, R. (1964). Narodnichestvo: A Semantic Inquiry. Slavic Review, v. 23, n. 3, pp. 441-458.

RETAMOZO, M. (2017). La teoría política del populismo: usos y controversias en América Latina en la perspectiva posfundacional. Latinoamérica. Revista de Estudios Latinoamericanos, v. 64 , pp. $125-151$.

ROTH, Y.; HARVEY, D. (2018). How Twitter is fighting spam and malicious automation. Available at: https://blog.twitter.com/en_us/topics/company/2018/how-twitter-isfighting-spam-and-malicious-automation.html. Accesd: March 10, 2020.

STANLEY, B. (2008). The thin ideology of populism. Journal of Political Ideologies, v. 13, n. 1, pp. 95-110.

TAGGART, P. (2002). Populism. New Delhi: Viva Books.

TAGUIEFF, P-A. (1997). Le popuiisme et la science politique: du mirage conceptuel aux vrai problémes. Vingtiéme Siécle. Revue d'bistoire, v. 56, pp. 4-33.

TWITTER (2010). To trend or not to trend. Available at: https://blog.twitter.com/official/ en_us/a/2010/to-trend-or-not-to-trend.html. Accessed: March 10, 2020.

VELKOVA, J.; KAUN, A. (2019) Algorithmic resistance: media practices and the politics of repair. Information, Communication \& Society, DOI: 10.1080/1369118X.2019.1657162.

VOLOSHINOV, V. N. (1929). Marxism and the Pbilosopby of Language. Cambridge: Harvard University Press, 1973.

WEYLAND, K. (2001). Clarifying a Contested Concept: Populism in the Study of Latin American Politics. Comparative Politics, v. 34, n. 1, pp. 1-22.

WODAK, R. (2015). The Politics of Fear. London: Sage.

Recebido: 11/03/2020

Aceito: 25/03/2020

Publicado: 6/04/2020 